\title{
Epidemiological trends in asthma
}

\author{
MALCOLM R SEARS MB ChB FRACP FRCPC \\ Firestone Regional Chest \& Allergy Unit, St Joseph's Hospital, McMaster University, \\ Hamilton, Ontario
}

MR SEARS. Epidemiological trends in asthma. Can Respir J 1996;3(4):261-268.

Many markers of asthma morbidity have shown substantial increases over the past two decades, including family physician visits, use of anti-asthma medications, emergency room visits and hospital admissions. The reported prevalence of diagnosed asthma and of wheezing has increased, especially in children, with accompanying evidence of increased atopy and increased airway responsiveness. Allergen exposure and parental smoking are significant risk factors for childhood wheezing, whereas the influence of outdoor air pollution is uncertain. Increasing use of betaagonist treatment, which appears to increase the severity of asthma by increasing early and late responses to allergen, may contribute to increased morbidity and mortality, especially if potent beta-agonists are used. Risk factors for asthma mortality include age, smoking, allergy and airway lability, as well as over-reliance on beta-agonists and poor compliance with other aspects of treatment. Following withdrawal of the potent beta-agonist fenoterol in New Zealand, both hospital admissions and mortality from asthma fell abruptly. Continued patient and physician education, with emphasis on avoidance of risk factors and use of appropriate treatment, should reduce morbidity and mortality from asthma in Canada.

Key Words: Asthma, Epidemiology

\section{Tendances épidémiologiques dans l'asthme}

RÉSUMÉ : De nombreux marqueurs de la morbidité liée à l'asthme ont démontré des augmentations substantielles au cours des vingt dernières années, y compris les visites chez le médecin de famille, l'utilisation des anti-asthmatiques, les visites à l'urgence et les hospitalisations. L'incidence rapportée de l'asthme diagnostiqué et des sibilances a augmenté, surtout chez les enfants et s'accompagne de signes d'atopie et d'hyperréactivité bronchique. Les expositions aux allergènes et le tabagisme parental sont des facteurs de risque significatifs pour le développement de sibilances chez l'enfant, tandis que l'influence de la pollution de l'air extérieur n'est pas certaine. L'utilisation accrue de bêta-agonistes pour le traitement de l'asthme, qui semble accroître la sévérité de l'asthme en augmentant les réponses précoces et tardives aux allergènes, pourrait contribuer à faire augmenter la morbidité et la mortalité, surtout si des bêta-agonistes puissants sont utilisés. Les facteurs de risque pour la mortalité due à l'asthme comprennent l'âge, le tabagisme, l'allergie et la labilité bronchique, ainsi qu' une trop grande confiance envers les bêta-agonistes, et une observance médiocre des autres aspects du traitement. En Nouvelle-Zélande, après le retrait du fénotérol, un puissant bêta-agoniste, les hospitalisations ainsi que la mortalité dues à l'asthme ont chuté soudainement. Une éducation continue des patients et des médecins qui met l'accent sur l'éviction des facteurs de risque et sur l'utilisation d'un traitement approprié devrait réduire la morbidité et la mortalité dues à l'asthme au Canada.

\section{TRENDS IN ASTHMA MORBIDITY}

Precise measurement of the prevalence of asthma is difficult, but a number of markers have been used to determine the burden of illness and to follow trends in morbidity. A 1988 report from the United Kingdom noted that the number of patients consulting their general practitioner had increased by over $80 \%$ between 1970 and 1982 , prescriptions for antiasthma drugs increased by $70 \%$ between 1977 and 1986, and hospital discharges increased by $100 \%$ between 1979 and 1984 (1). These trends suggested a substantial increase in morbidity from asthma in the United Kingdom during the 1970s and 1980s.

Correspondence and reprints: Dr MR Sears, Asthma Research Group, McMaster University, Firestone Regional Chest and Allergy Unit, St Joseph's Hospital, 50 Charlton Avenue East, Hamilton, Ontario L8N 4A6. Telephone 905-522-1155 ext 3286, fax 905-521-6132, e-mail searsm@fhs.csu.mcmaster.ca 


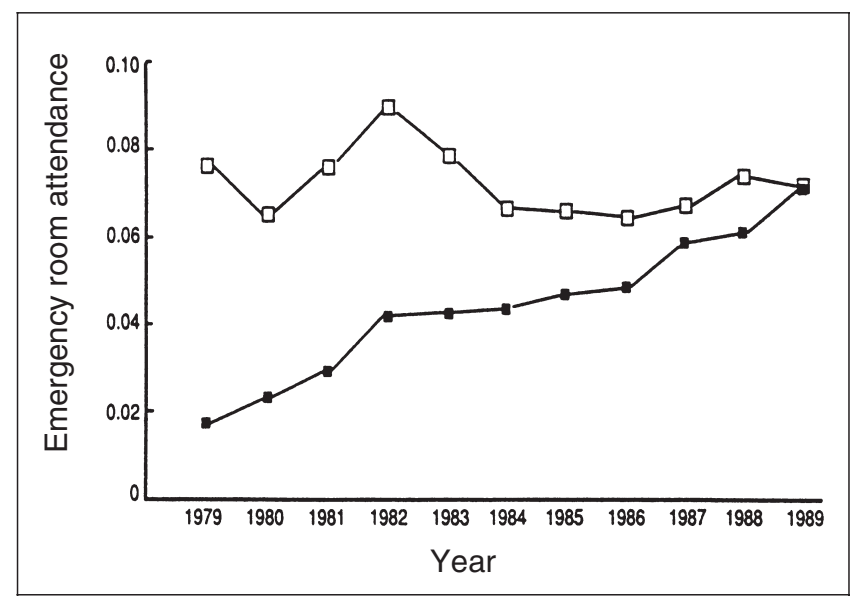

Figure 1) The ratio of attendances for asthma to all emergency room attendances $(\square)$ compared with the ratio of attendances for nonasthma respiratory conditions to all attendances ( $\square$ ) in an Australian children's hospital (reprinted from reference 3: Kun $\mathrm{HY}$, Oats RK, Mellis CM. Hospital admissions and attendances for asthma - a true increase? Med J Aust 1993;159:312-3. (C) Copyright 1993 The Medical Journal of Australia. Reproduced with permission)

Emergency room visits for asthma are more easily ascertained than general practice visits. In Oregon, asthma episodes among children from birth to 14 years of age were estimated from emergency room attendances of health plan members (2). It was estimated that the number of emergency room visits by these individuals rose fourfold in 20 years, from 200/100,000 person-years in 1967-69 to over $800 / 100,000$ person-years in 1985-87. The increase was more substantial in boys and less evident in girls. In an Australian children's hospital, the ratio of emergency room attendances for asthma to the total number of attendances was compared with the ratio of attendances for nonasthmatic respiratory conditions to total attendances during the period 1979 to 1989 (3). The proportion of asthma attendances increased threefold, while nonasthma respiratory attendances at emergency rooms were stable (Figure 1).

Hospital admissions represent asthmatics of an even greater severity. In the same Australian children's hospital, the ratio of admissions for asthma to total admissions approximately doubled from 1979 to 1989 , while the ratio of nonasthma respiratory admissions to total admissions remained stable (3). The increase in hospital admissions of children with asthma, which has been seen in many countries, appears to be more marked among the young, particularly from birth to four years of age, and is less marked among children five to 17 years of age, as reported from the United States National Center for Health Statistics (4). The increase in admissions in the United States is much more striking in urban African-American children than in urban Caucasian children or rural children (5). In the United Kingdom, admissions for childhood asthma were again more clearly increasing among children from birth to four years of age, followed by children five to 14 years of age, with only slight increases in older populations (6).

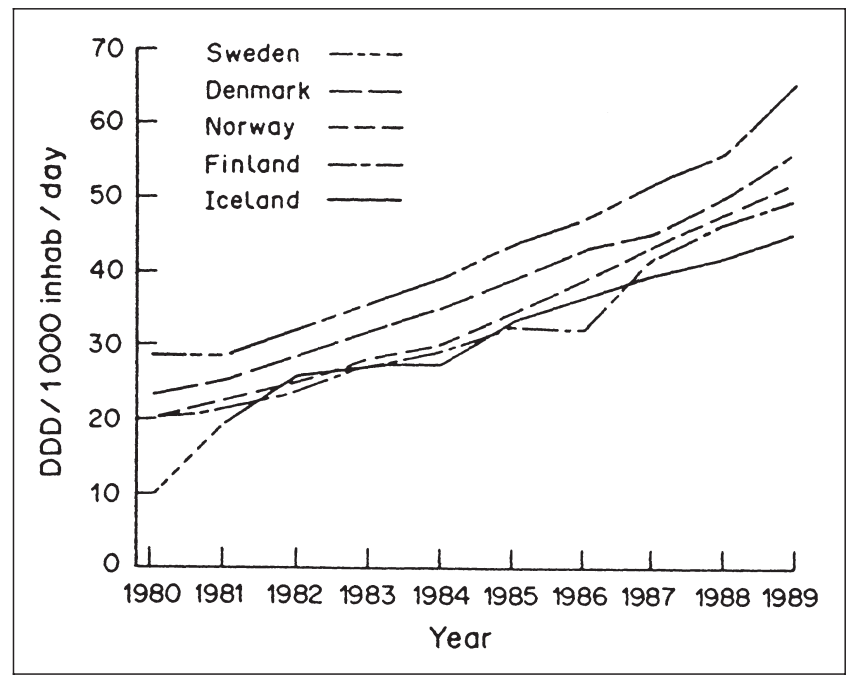

Figure 2) Sales of anti-asthmatic drugs in five Nordic countries. DDD Defined daily dose (reprinted with permission of the publisher from reference 8: Klaukka T, Peura S, Martikainen J. Why has the utilization of antiasthmatics increased in Finland? J Clin Epidemiol 1991;44:859-63. Copyright 1991 by Elsevier Science Inc)

Drug sales are a less direct marker of morbidity, because anti-asthmatic drugs may also be used for nonasthmatic airflow obstruction such as bronchitis and emphysema. However, a New Zealand study found that $80 \%$ of sales of salbutamol were for asthma (7). In five Nordic countries (Sweden, Denmark, Norway, Finland and Iceland) studied from 1980 to 1989, there was a significant upward trend in drug sales approximating a twofold increase in each country (8) (Figure 2). More important, the number of drugs prescribed per patient increased significantly. In 1976, 35\% of asthmatic patients in Finland received no medication. A further 35\% received only one drug, 21\% two drugs and 9\% three or more drugs. By 1987, only $17 \%$ received no medication, $26 \%$ received one drug, $28 \%$ two drugs and $29 \%$ three or more drugs. Hence, not only is there more asthma, but more drug therapy is being used for individual asthmatics to control asthma (8). This may represent better care, but could also reflect more severe disease.

Serial measurements of community prevalence of disease pose several difficulties because of changing populations, changing methodology, and an increased awareness of asthma and readiness to use the label 'asthma' for wheezing disorders. Reported prevalence of diagnosed 'asthma' in primary school children in Australia increased from less than $5 \%$ in 1967 to over $15 \%$ by 1990 (9). However, a substantial proportion of this increase may be due to diagnostic classification, resulting from greater recognition of wheezing as asthma (10). A similar review of the prevalence of recent 'wheezing' (occurring within the previous 12 months) in primary school children in Australia shows that prevalence has increased from $10 \%$ to $15 \%$ in the early 1980 s to $20 \%$ to $25 \%$ in the early 1990s (9). Prevalence studies in other countries have similarly shown increases when either wheezing or asthma has been the subject of study, but increases in 
'asthma' prevalence are generally greater than increases in wheezing, suggesting a diagnostic trend towards a label of asthma (11).

A number of investigators have administered identical or near-identical questionnaires in the same region to the same age group at intervals of years or decades. One of the most well-known was undertaken in Aberdeen, Scotland in 1964 and repeated in 1989 (12). In that study, the prevalence of wheezing increased from $10 \%$ in 1964 to $20 \%$ in 1989 , shortness of breath from $6 \%$ to $10 \%$, and asthma from $4 \%$ to $10 \%$. The prevalence of other atopic diseases also increased, eczema rising from $6 \%$ to $12 \%$, and hay fever from $3 \%$ to $12 \%$. The recognition of wheezing as being due to asthma also changed between the 1964 and 1989 survey. In 1964, of all those with wheezing, only $27 \%$ had a label of asthma, whereas by 1989 this had increased to $50 \%$. Those with one to three episodes of shortness of breath per year were labelled as asthmatic in only $25 \%$ of cases in 1964, whereas by 1989 , this label was given to $70 \%$. Those with more than five episodes per year were recognized as having asthma in only $60 \%$ of cases in 1964, but in almost 90\% in 1989 (Figure 3). Hence, the increasing prevalence of reported 'asthma' can be substantially explained by an increasing recognition that wheeze, particularly more frequent wheeze, is due to asthma.

In a further study of eight- to 13-year-olds in Aberdeen in 1994, the prevalence of wheeze in the previous three years had increased from $19.8 \%$ (95\% CI 18.8 to 21.2 ) to $25.3 \%$ (24.0 to 26.7) between 1989 and 1994, and diagnosed asthma had increased from $10.2 \%$ (8.9 to 11.0 ) to $19.5 \%$ (18.3 to 20.7). The proportion of wheezing diagnosed as asthma had increased from $49 \%$ to $64 \%$ (13).

Objective markers of asthma, or airway responsiveness, may be more reliable indicators of changes in prevalence than symptoms or diagnosis alone. Burr et al (14) performed exercise tests on 12-year-old children in South Wales in 1973 $(n=818)$ and $1988(n=960)$. The prevalence of wheeze had increased from $6 \%$ to $12 \%$, while a history of hay fever increased from $9 \%$ to $15 \%$ and of eczema from $5 \%$ to $16 \%$. There was objective evidence of more exercise-induced fall in peak flow in 1988 than in 1973, in that $4.1 \%$ had greater than $25 \%$ fall in peak expiratory flow rate following standardized exercise in 1988, compared with 2.0\% in 1973.

\section{RISK FACTORS FOR ASTHMA}

A number of factors may play some role in the increased prevalence of asthma. Those that have been most clearly defined in children are increasing atopy, environmental tobacco smoke exposure and early childhood infection. The role of air pollution is uncertain but probably is not of major importance as an initiating factor in asthma. In most countries, air pollution has decreased, yet asthma has increased. Air pollution may have an influence on manifestations of atopy, as may smoking (15). Occupational exposures are significant risk factors for adult-onset asthma, although the increasing prevalence is in part due to increased recognition of this condition and acceptance of a wider range of sensitizing or irritant substances as being causally related.

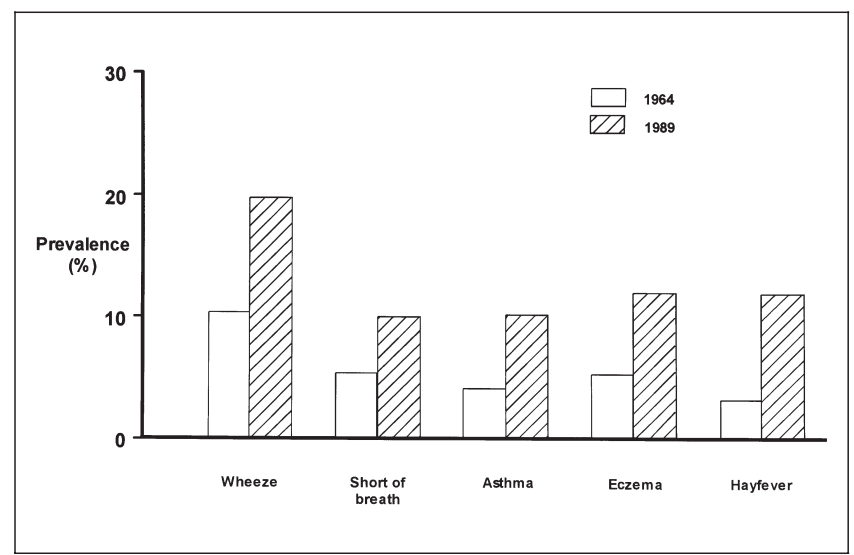

Figure 3) Prevalence of wheeze, diagnosed asthma, hay fever and eczema in Aberdeen, Scotland children studied in 1964 and 1989 (adapted with permission from reference 12: Ninan TK, Russell G. Respiratory symptoms and atopy in Aberdeen schoolchildren: evidence from two surveys 25 years apart. BMJ 1992;304:873-5)

Evidence of increasing atopy comes from a number of studies. Taylor et al (16) reviewed the prevalence of eczema in early childhood in three studies. Six-year-olds born in 1946 had a prevalence of eczema of 5\%, whereas seven-year-olds born in 1958 had a prevalence of $7.5 \%$, and five-year-olds born in 1970 had a prevalence of $12 \%$. Although the ages and the questions were slightly different, this finding strongly suggested an increasing prevalence of atopic dermatitis. Nakagomi et al (17) reported on levels of specific immunoglobulin (Ig) E in 13- to 14-year-old school girls in Japan, who had specific IgE to one or more of 16 allergens tests. The prevalence of specific IgE was $21.4 \%$ in 1978 and increased to $25.0 \%, 35.5 \%$ and $39.4 \%$, respectively, in 1981,1985 and 1991. Evidence of an increasing trend to atopic disease is seen in many countries, but the reasons for this are not defined. The effect of dietary changes over the years is one hypothesis, but data are not yet convincing.

The effect of maternal smoking in early childhood has been identified in several studies as a risk factor for development of wheezing symptoms and of airway hyperresponsiveness (AHR) in young children. Frisher et al (18) showed that among 1812 first-grade children who participated in an exercise test of airway responsiveness, exposure to maternal smoking during the first year of life increased the odds ratio for exercise airway responsiveness to 2.82 (95\% CL 1.25 , 6.34). This and other studies $(19,20)$ have shown that maternal smoking is a more potent provocation to development of wheezing than is paternal smoking. Intrauterine exposure and exposure during the first few months of life appear to be critical in increasing the risk of wheezing in the young child $(21,22)$.

Data from a longitudinal study of New Zealand children demonstrate that those who have histories of childhood wheezing and who are exposed to parental smoking have progressively impaired lung function over late childhood and early adolescence, whereas wheezing children not exposed to parental smoking show improvements in lung function with 
return to normal or near normal by age 15 (23). Hence, passive smoking may be associated not only with the development of early childhood asthma, but also with its persistence and worsening over time.

The impact of outdoor air pollution on development of asthma, and on increasing morbidity from asthma, remains uncertain (24). While episodes of markedly increased air pollution are associated with increased hospital admissions for asthma (indicating an exacerbating effect on preexisting asthma) (25), prevalence rates for asthma are lower in areas of high pollution (eg, the former East Germany) than in less polluted areas (the former West Germany), suggesting that development of asthma is not directly influenced by outdoor air pollution (26). In a four-centre comparison in Canada, respiratory symptoms were higher in Hamilton, a more industrial city, than in Vancouver, but this may reflect more than simply 'asthma' (27).

Indoor air pollution, particularly exposure to house dust mite allergen and to animal dander, especially cats, is a major risk factor for development of asthma in many countries (28). Peat and colleagues (29) in Australia showed in a population sample of 1339 children aged eight to 11 years that the odds ratio for developing asthma was markedly elevated at 7.0 if the subject was house dust mite-sensitive. The development of symptoms of both asthma and of AHR related strongly to the degree of house dust mite sensitivity. In these children in Sydney, the mean level of house dust mite allergen Der $p$ I in the home was $22.5 \mu \mathrm{g} / \mathrm{g}$ of dust, a very high level of exposure and typical of many areas in Australia and New Zealand.

The relative contribution of many factors in infancy and early childhood to the development of childhood asthma has been studied in a cohort of New Zealand children followed from birth to age 18 years (30). Male sex was a significant independent predictor for atopy, AHR, hay fever and asthma developing by age nine. A positive family history, especially maternal, of asthma strongly predicted childhood atopy, AHR, asthma and hay fever. Maternal smoking in the last trimester of pregnancy was related to the onset of asthma by age one $(\mathrm{P}=0.049)$. The number of siblings, position in the family, socioeconomic status and birth-weight were not consistently predictive of any characteristic of asthma in that study, although others have reported small effects related to each of these factors (31-36).

\section{INCREASING SEVERITY OF ASTHMA}

There is considerable evidence to suggest increasing severity of asthma, including increased hospital admissions for asthma (which have exceeded any increase in prevalence), which is not explained by admission of patients with less severe asthma. On the contrary, the severity of asthma in those now admitted to hospital is at least equal to that of one or two decades ago, and is probably greater (37). Despite increasing sale of anti-asthma drugs, which are used primarily for asthma, many prevalence studies report apparent undertreatment of asthma. These features are consistent with the impression that not only has there been a gradual increase in prevalence of asthma, but there has also been a substantial (and more striking) increase in severity of asthma, which accounts for many of these trends.

Among factors that may have contributed to an increase in severity of asthma are increased exposure to allergen, perhaps related to changes in housing with greater insulation, warmth and humidity favouring house dust mite survival and proliferation (38), and the ubiquitous nature of cat allergen, which is widespread throughout the community even where no cat is present (39).

A major cause of controversy is the suggestion that certain treatments of asthma may increase morbidity and severity. Particular emphasis has been placed on the role of short acting inhaled beta-agonists which, when used frequently, particularly in high dosage, may increase severity of asthma by increasing airway responsiveness (40). Adverse effects were most clearly documented in a randomized, placebo controlled, crossover study in New Zealand, in which 64 patients were randomized to receive either fenoterol dry powder $400 \mu \mathrm{g}$ qid or matching placebo for 24 weeks and then crossed over to the alternate regimen $(41,42)$. In this study, there was clear evidence of deterioration in asthma control during regular inhaled beta-agonist treatment, with lower forced expiratory volume in $1 \mathrm{~s}\left(\mathrm{FEV}_{1}\right)$, lower vital capacity, increased airway responsiveness, lower morning peak flow rates, increased diurnal variation in peak flow, earlier occurrence of exacerbations and slightly greater number of exacerbations during regular treatment. Overall, $70 \%$ of subjects showed worse control during regular treatment $(\mathrm{P}=0.003)$. This deleterious effect of large doses of beta-agonist may be a substantial factor accounting for the increased severity of asthma, which affects trends in morbidity, including emergency room and hospital visits, antiasthma drug sales and perhaps mortality.

Confirmation that regular use of beta-agonist can increase the severity of asthma has come from carefully controlled studies in Saskatoon and Hamilton. Regularly inhaled salbutamol, two puffs qid for one or two weeks, increased the severity of the early response (43) and the late response (44) to allergen challenge. By using induced sputum to study airway inflammation, it has been shown that the regular use of inhaled salbutamol increases the number of blood eosinophils and neutrophils, and the influx of metachromatic cells $24 \mathrm{~h}$ after allergen (45). Regular inhalation of salbutamol has also been shown to increase exercise-induced bronchoconstriction (46).

While a few studies have not found any deleterious effect of regular salbutamol on control of asthma, $(47,48)$, several preliminary studies report benefit from reduction of betaagonist use in reducing morbidity and mortality (49-51).

\section{TRENDS IN ASTHMA MORTALITY}

Two epidemics of asthma mortality have been documented. The first occurred in Australia, New Zealand and the United Kingdom between 1964 and 1968, associated in time with the marketing in these countries of high dose isoprenaline (52). Appropriate studies to determine the cause of the epidemic were not undertaken, but the rise in deaths 


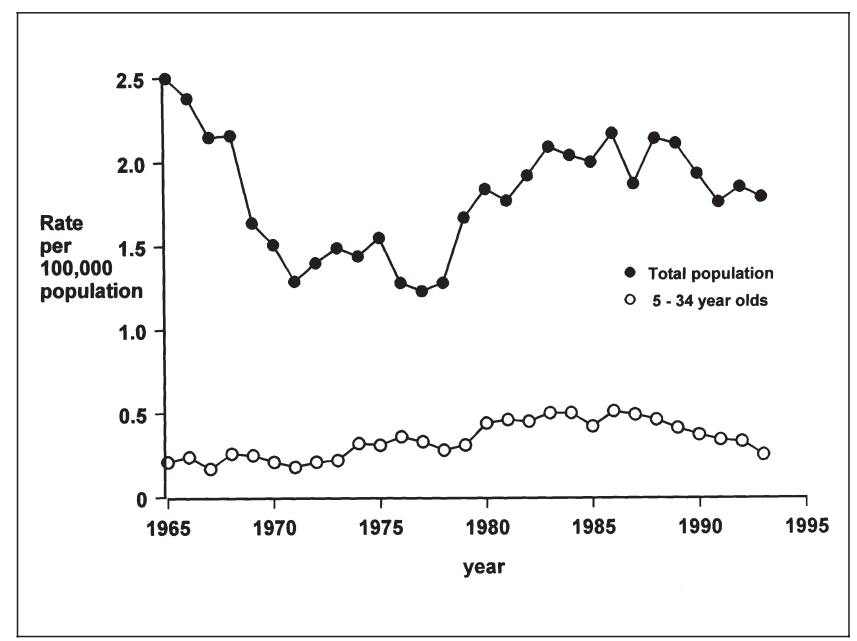

Figure 4) Asthma mortality rates in Canada 1970 to 1993, for total population, and for five- to 34-year-olds. Data from Health and Welfare Canada

concomitant with marketing of this high dose inhaler and the subsequent fall in deaths when warnings were issued about the possible link with this preparation suggested that there may have been an association. This was debated for two decades without resolution, but recent studies have shed further light on this issue.

The second epidemic of asthma mortality occurred only in New Zealand, where in 1977 there was an abrupt increase in mortality among young people five to 34 years of age, from rates of 1.5/100,000, up to and exceeding 4.0/100,000 (53). This trend persisted over several years, leading to a number of investigations. At the same time, a more gradual upward trend in asthma mortality was observed in many other countries, including the United States, where deaths in young people from birth to 34 years of age increased from a nadir of 220 deaths in 1977 to over 500 deaths in 1987 (54). In the United Kingdom, mortality from asthma in all age groups increased significantly in both males and females from a nadir in 1976 of 1.6 (males) and 2.1 (females) to levels around 3.0 /100,000 for both sexes in 1991 (55). In Canada, mortality in young people aged five to 34 years more than doubled between $1970 \quad(0.21 / 100,000)$ and 1986 $(0.51 / 100,000)$, but since 1987 has been gradually decreasing towards the level of the 1970s (Figure 4).

\section{RISK FACTORS FOR ASTHMA MORTALITY}

Cohort studies have been undertaken examining the circumstances surrounding deaths of asthmatics in New Zealand $(56-58)$, the United Kingdom $(59,60)$ and the United States $(61,62)$. These studies have consistently revealed that asthma mortality is associated with poor patient compliance, discontinuity of medical care, a history of previous lifethreatening attacks, underassessment of severity, overreliance on bronchodilators, underuse of corticosteroids, both long term and during the acute attack, and delays in seeking

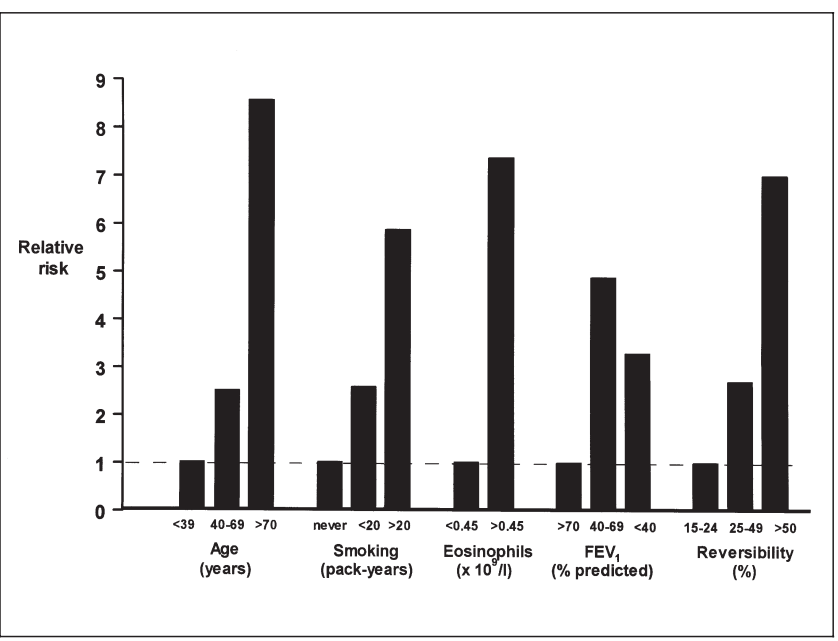

Figure 5) Relative risks for mortality in a prospective Netherlands cohort of asthmatics. FEV 1 Forced expiratory volume in $1 \mathrm{~s}$ (adapted with permission from reference 64: Ulrik CS, Frederiksen J. Mortality and markers of risk of asthma death among 1,075 outpatients with asthma. Chest 1995;108:10-5)

help during the acute attack. Most deaths from asthma are associated with a gradual deterioration over hours, days or weeks, in which many factors play a part including psychological features of the patient and family, with compounding social, cultural and economic factors, which often lead to acceptance of disability and disregard of asthma symptoms. These may in turn lead to late presentations for acute care of severe episodes and poor use of corticosteroids. These circumstances result in death that should have been preventable. A small group of patients have acute severe episodes with sudden onset of severe airway closure leading to death within minutes or 1 to $2 \mathrm{~h}$ at most. These acute episodes may be associated with severe allergen exposure and anaphylactictype reactions, but mechanisms have not been fully elucidated (63).

Although many studies have examined circumstances under which patients with severe asthma die, and blame has been attributed to noncompliant patients, impaired access to care, medical mismanagement and many other factors, a fundamental question cannot be answered by cohort and case control studies. Why did the patient have asthma of such severity as to be at risk of a fatal attack? Several characteristics of asthma can be used to predict risks of death, as shown in a longitudinal follow-up study by Ulrik and Frederiksen (64), who reviewed a cohort of asthmatics in the Netherlands followed over many years. Relative risk of death increased with increasing age, particularly over 70 (relative risk 8.5 compared with age under 40) and with smoking over 20 pack-years (relative risk 5.9 compared with never-smokers) (Figure 5). Blood eosinophilia greater than $0.45 \times 10^{9} / \mathrm{L}$ gave a relative risk of 7.4 compared with eosinophilia below that level. Risks associated with impaired lung function were interesting, and somewhat different from what might have been expected. Compared with those with $\mathrm{FEV}_{1}$ greater than $70 \%$ predicted as the reference group, those with $\mathrm{FEV}_{1} 40 \%$ 


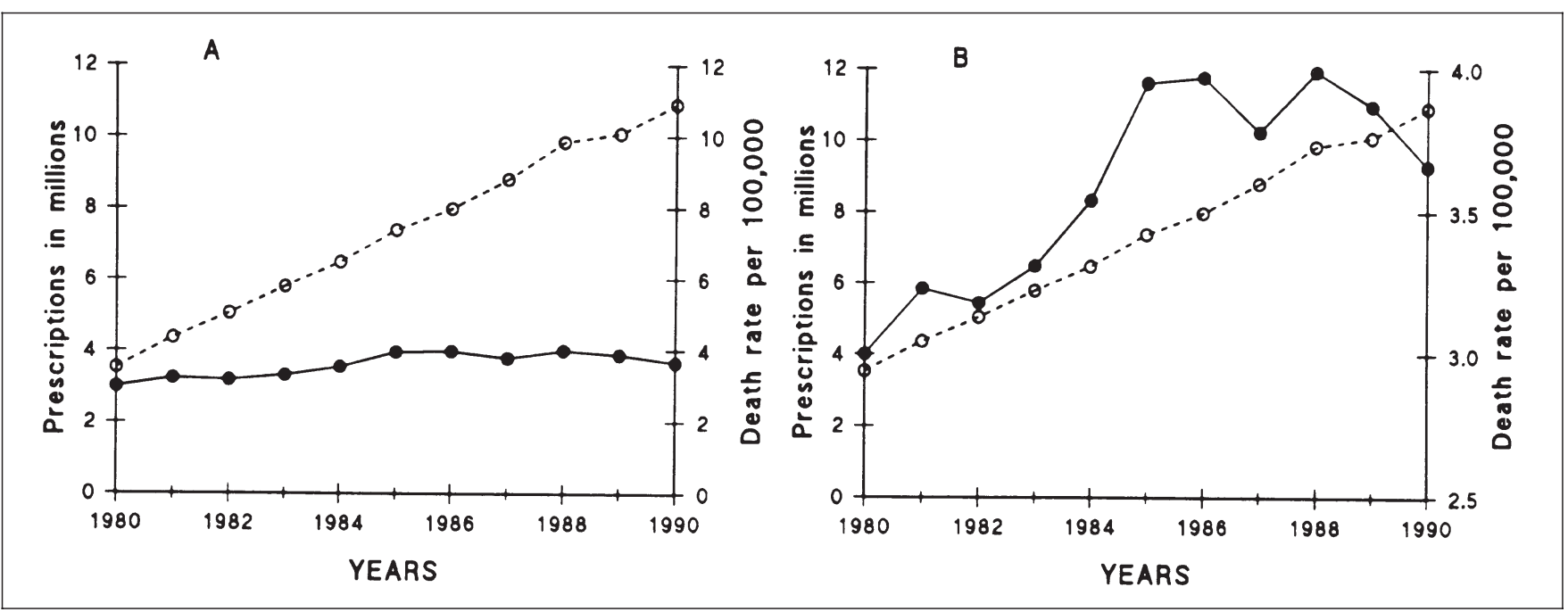

Figure 6) Relationship between sales of beta-agonists (O) in the United Kingdom and trends in asthma mortality (O), 1980 to 1990. A and B show the same data plotted using different Y-axes (reprinted with permission from reference 69: Taylor DR, Sears MR. Regular beta-adrenergic agonists. Evidence, not reassurance, is what is needed. Chest 1994;106:552-9)

to $69 \%$ predicted had the highest relative risk of 4.9 , while those with $\mathrm{FEV}_{1}$ less than $40 \%$ predicted had a lesser increased risk of 3.3, indicating that those with more severe airflow obstruction are at lower risk than those with moderate airflow obstruction. This is perhaps further explained by their findings regarding reversibility. Compared with those with $15 \%$ to $24 \%$ reversibility, taken as the reference group, those with $25 \%$ to $49 \%$ reversibility had a relative risk of 2.7 and those with greater than $50 \%$ reversibility had a much higher relative risk of 7.0. Hence, those with more reversible asthma, whose lung function may not be as severely obstructed, and those with marked increase in eosinophilia are at particular risk of death from asthma. One might infer that these patients are more susceptible to sudden acute episodes of asthma when exposed to allergen.

The impact of drug treatment on asthma mortality has been debated widely over recent years. The most well-known study was conducted in Saskatchewan, where a dose-response relationship between the number of inhalers of beta2agonist used per year and the risk of death was found (65). The relative risks were higher for those using fenoterol, which was marketed at $200 \mu \mathrm{g}$ per puff, compared with salbutamol, marketed at $100 \mu \mathrm{g}$ per puff, but when the drugs were adjusted for dose equivalence, remarkably similar relative risks were associated with increasing use of inhalers. Nevertheless, the highest risks still pertained to use of more than 13 fenoterol inhalers per year. This study can be interpreted as showing that increased use of beta-agonist inhalers is a marker of severity of asthma, indicating an increased risk of mortality, or alternatively that increased use of inhalers may be causally associated with increased mortality. This question cannot be fully answered by this or any other case control epidemiological studies, although the risks associated with beta-agonist use were not substantially altered by adjusting for confounding factors (66). A trend to increasing inhaler use is a major predictor of an unfavourable outcome.
An increase in use of one inhaler per month is a serious warning of an impending life-threatening attack of asthma (67). The findings from the randomized controlled trial of regular fenoterol versus as-needed beta-agonist would lend support to the hypothesis that increasing use of beta-agonist may per se increase severity of asthma and therefore increase the risk of fatal asthma (40-42).

In response to concerns about the safety of beta-agonist treatment, various advisory groups and administrations have looked at the available data. The Committee on Safety of Medicines in the United Kingdom plotted the threefold increase in prescriptions of beta-agonists between 1980 and 1990, from less than four million to approximately 11 million during this time, against mortality from asthma in all age groups and in the under 65-year-olds, showing an apparent disassociation with mortality being virtually stable while prescriptions increased threefold (68). However, the graph is falsely reassuring, because mortality rates were plotted on a very wide scale, making the upward trend appear almost flat. Replotting these data on a more appropriate scale suggests that there could be a relationship between increasing sales and increasing mortality (69). Neither plot proves or disproves the association, but the initial presentation may be falsely reassuring (Figure 6).

Some have expressed doubts about the hypothesis that frequent use of beta-agonists may increase severity of asthma leading to increased morbidity and mortality (70-72). This is understandable given that most asthmatics have mild asthma, and a small shift in severity within the mild asthmatic group would not be appreciated because of the variable nature of asthma, unless specific studies are undertaken. However, given that a few subjects may move from having mild asthma to moderate asthma, at which time they are likely to be given more beta-agonist and more potent beta-agonists when these are marketed (eg, high dose isoprenaline and fenoterol), it is likely that some individuals developed even more severe 
asthma and this accounted for increasing morbidity as measured by general practitioner visits, hospital admissions, emergency room visits, etc. With increased severity, these patients were given high doses of beta-agonists along with other treatments including corticosteroids, but several studies have now clearly shown that even high dose inhaled corticosteroids do not protect against the deleterious effect of regular beta-agonist use. This hypothesis explains the increased number of people at risk of death from asthma, because of the increased pool of severe asthmatics. Within that group at higher risk, adverse circumstances, including social, ethnic and medical management and access issues, may all conspire to provide the scenario during which a severe attack of asthma may be fatal $(40,65)$.

Recent trends in morbidity and mortality in New Zealand, following the withdrawal of fenoterol in 1990, are strongly supportive of this hypothesis. Not only has mortality fallen abruptly, to rates below those pertaining before the epidemic began in the mid-1970s, but morbidity has also fallen abruptly as measured by hospital admissions and emergency room visits (73) (Figure 7). The severity of disease in subjects who have been weaned off high dose fenoterol or frequent use of salbutamol has generally decreased. A decrease in morbidity and severity of asthma clearly cannot be related to any cardiac effects of beta-agonist. Hence it is also most unlikely that the increase then decrease in mortality is related to cardiac toxicity, but rather relates to changes in asthma severity.

Several allergen-related factors may increase the severity of asthma, to which attention can also be directed to reduce severity and improve morbidity and mortality. These factors include the degree of allergen exposure, the potential for masking of ongoing inflammation by reliance on symptomatic treatment, as well as the direct deleterious effects of frequent use of a beta-agonist, at least in part due to their documented ability to increase both the early asthmatic reaction and the late asthmatic reaction to allergen inhalation $(43,44)$.

\section{REFERENCES}

1. Cullinan P. Respiratory disease in England and Wales. Thorax 1988;43:949-54

2. Vollmer WM, Osborne ML, Buist AS. Temporal trends in hospital-based episodes of asthma care in a health maintenance organization. Am Rev Respir Dis 1993;147:347-53.

3. Kun HY, Oates RK, Mellis CM. Hospital admissions and attendances for asthma - a true increase? Med J Aust 1993;159:312-3.

4. Gergen PJ, Weiss KB. Changing patterns of asthma hospitalization among children: 1979 to 1987. JAMA 1990;264:1688-92.

5. Gerstman BB, Bosco LA, Tomita DK. Trends in the prevalence of asthma hospitalization in the 5 to 14 year old Michigan Medicaid population, 1980 to 1986 . J Allergy Clin Immunol 1993;91:838-43.

6. Costello J. Asthma - the problem and the paradox. Postgrad Med J 1991;67:S1-5.

7. Sinclair BL, Clark DWJ, Sears MR. Use of anti-asthma drugs in New Zealand. Thorax 1987;42:670-5.

8. Klaukka T, Peura S, Martikainen J. Why has the utilization of antiasthmatics increased in Finland? J Clin Epidemiol 1991;44:859-63.

9. Bauman A. Has the prevalence of asthma symptoms increased in Australian children? J Paediatr Child Health 1993;29:424-8.

10. Sears MR. Epidemiology. In: Barnes PJ, Rodger IW, Thomson NC, eds. Asthma: Basic Mechanisms and Clinical Management, 2nd edn. San Diego: Academic Press 1992:1-19.

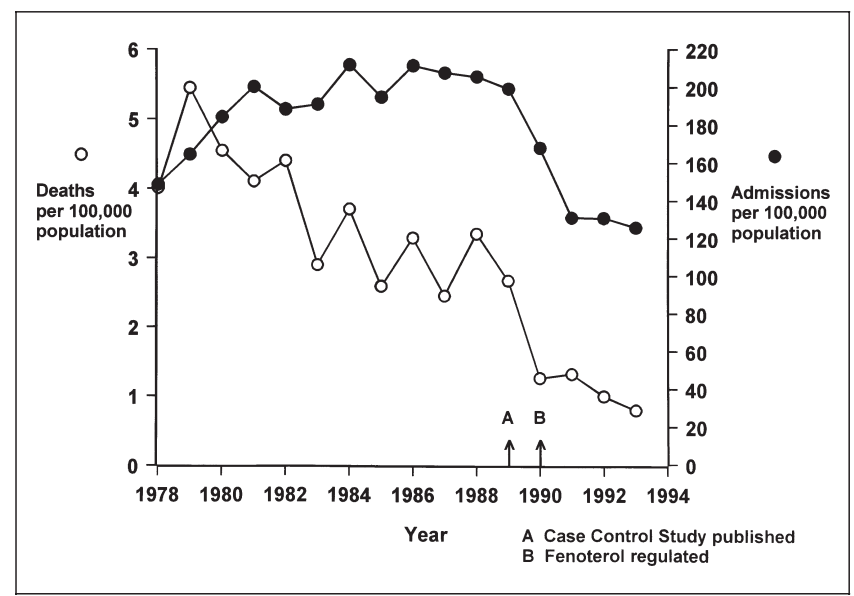

Figure 7) Abrupt decrease in asthma-related hospital admissions and mortality in New Zealanders aged 15 to 44 years following withdrawal of fenoterol in 1990

\section{IMPLICATIONS}

What action can be taken to reduce asthma morbidity and mortality? Reduction in exposures known to be associated with increased morbidity, including exposure to house dust mite, cat allergen and environmental tobacco smoke, is a logical first step. Discouragement of inappropriate treatments, including overreliance on beta-agonists and encouragement of appropriate treatment by early use of anti-inflammatory therapy, specifically inhaled corticosteroids, should reduce morbidity and mortality. These actions require extensive education for health care professionals and asthmatics in optimum management of asthma. Two national asthma education conferences have been held in Canada in the past three years, and revised guidelines for management of asthma in Canada have been published in this journal recently (74). Hopefully these steps to disseminate current thinking regarding optimum management will further reduce morbidity and mortality from asthma in this country.

11. Whallett EJ, Ayres JG. Labelling shift from acute bronchitis may be contributing to the recent rise in asthma mortality in the 5-34 age group. Respir Med 1993;87:183-6.

12. Ninan TK, Russell G. Respiratory symptoms and atopy in Aberdeen schoolchildren: evidence from two surveys 25 years apart. BMJ 1992;304:873-5.

13. Omram M, Russell G. Continuing rise in the prevalence of asthma-like symptoms and diagnosed atopic disease in Aberdeen schoolchildren. Eur Respir J 1995;8(Suppl 19):495s.

14. Burr ML, Butland BK, King S, Vaughan-Williams E. Changes in asthma prevalence: two surveys 15 years apart. Arch Dis Child 1989;64:1452-6.

15. Burney PGJ, Bousquet J. Evidence for an increase in atopic disease and possible causes. Clin Exp Allergy 1993;23:484-92.

16. Taylor B, Wadsworth J, Wadsworth M, Peckham C. Changes in the reported prevalence of childhood eczema since the 1939-45 war. Lancet 1984;ii:1255-7.

17. Nakagomi T, Itaya H, Tominaga T, Yamaki M, Hisamatsu S, Nakagoma O. Is atopy increasing? Lancet 1994;343:121-2.

18. Frischer T, Kuehr J, Meinert R, et al. Maternal smoking in early childhood: a risk factor for bronchial responsiveness to exercise in primary school children. J Pediatr 1992;121:17-22.

19. Taylor B, Wadsworth J. Maternal smoking during pregnancy and lower respiratory tract illness in early life. Arch Dis Child $1987 ; 62: 786-91$. 
20. Weiss ST. Environmental tobacco smoke and asthma. Chest 1993;104:991-2.

21. Cunningham J, Dockery DW, Speizer FE. Maternal smoking during pregnancy as a predictor of lung function in children. Am J Epidemiol 1994;139:1139-52.

22. Oryszczyn MP, Godin J, Annesi I, Hellier G, Kauffmann F. In utero exposure to parental smoking, cotinine measurements, and cord blood IgE. J Allergy Clin Immunol 1991;87:1169-74.

23. Sherrill DL, Martinez FD, Lebowitz MD, et al. Longitudinal effects of passive smoking on pulmonary function in New Zealand children. Am Rev Respir Dis 1992;145:1136-41.

24. Schmitzberger R, Rhomberg K, Buchele H, et al. Effects of air pollution on the respiratory tract of children. Pediatr Pulmonol 1993;15:68-74.

25. Walters S, Griffiths RK, Ayres JG. Temporal association between hospital admissions for asthma in Birmingham and ambient levels of sulphur dioxide and smoke. Thorax 1994;49:133-40.

26. Von Mutius E, Martinez FD, Fritzsch C, Nicolai T, Roell G, Thiemann $\mathrm{HH}$. Prevalence of asthma and atopy in two areas of West and East Germany. Am J Respir Crit Care Med 1994;149:358-64.

27. Manfreda J, Yeung M, Dimich-Ward H, et al. Prevalence of asthma-like symptoms in four Canadian cities. Am J Respir Crit Care Med 1995;151:A29.

28. Sears MR, Herbison GP, Holdaway MD, Hewitt CJ, Flannery EM, Silva PA. The relative risks of sensitivity to grass pollen, house dust mite and cat dander in the development of childhood asthma. Clin Exp Allergy 1989;19:419-24.

29. Peat JK, Tovey E, Gray EJ, Mellis CM, Woolcock AJ. Asthma severity and morbidity in a population sample of Sydney schoolchildren: Part II - importance of house dust mite allergens. Aust NZ J Med 1994;24:270-6.

30. Sears MR, Holdaway MD, Flannery EM, Herbison GP, Silva PA. Parental and neonatal risk factors for atopy, airway hyperresponsiveness and asthma in children. Arch Dis Child. (In press)

31. von Mutius F, Martinez FD, Fritzsch C, Nicolai T, Reitmeir P, Thiemann HH. Skin test reactivity and number of siblings. BMJ 1994;308:692-5.

32. Seidman DS, Laor A, Gale R, Stevenson DK, Danon YL. Is low birth weight a risk factor for asthma during adolescence? Arch Dis Child 1991;66:584-7.

33. Arshad SH, Hide DW. Effect of environmental factors on the development of allergic disorders in infancy. J Allergy Clin Immunol 1992;90:235-41.

34. Kuehr J, Frischer T, Karmaus W, Meinert R, Barth R, Urbanek R. Clinical atopy and associated factors in primary-school pupils. Allergy 1992;47:650-5.

35. Chan KN, Elliman A, Bryan E, Silverman M. Clinical significance of airway responsiveness in children of low birthweight. Pediatr Pulmonol 1989;7:251-8.

36. Backer V, Ulrik SU, Hansen KK, Laursen EM, Dirksen A, Bach-Mortensen N. Atopy and bronchial responsiveness in a random population sample of 527 children and adolescents. Ann Allergy 1992;69:116-22.

37. Rea H, Sears M, Mitchell E, Garrett J, Mulder J, Anderson R. Is asthma becoming more severe? Thorax 1987;42:736.

38. De Andrade AD, Birnbaum J, Lanteaume A, et al. Housing and house-dust mites. Allergy 1995;50:142-6.

39. Custovic A, Taggart SCO, Woodcock A. House dust mite and cat allergen in different indoor environments. Clin Exp Allergy 1994;24:1164-8.

40. Sears MR, Taylor DR. The $\beta_{2}$-agonist controversy. Observations, explanations and relationship to asthma epidemiology. Drug Saf 1994;11:259-83.

41. Sears MR, Taylor DR, Print CG, et al. Regular inhaled beta-agonist treatment in bronchial asthma. Lancet 1990;336:1391-6.

42. Taylor DR, Sears MR, Herbison GP, et al. Regular inhaled beta-agonist in asthma: effect on exacerbations and lung function. Thorax 1993;48:134-8.

43. Cockcroft DW, McPaarland CP, Britto SA, Swystun VA, Rutherford BC. Regular inhaled salbutamol and airway responsiveness to allergen. Lancet 1993;342:833-7.

44. Cockcroft DW, O'Byrne PM, Swystun VA, Bhagat R. Regular use of inhaled albuterol and the allergen-induced late asthmatic response. J Allergy Clin Immunol 1995;96:44-9.
45. Gauvreau GM, Watson RM, Jordana M, Cockcroft D, O’Byrne PM. The effect of regular inhaled salbutamol on allergen-induced airway responses and inflammatory cells in blood and induced sputum. Am J Respir Crit Care Med 1995;151:A39.

46. Inman MD, O'Byrne PM. The effect of regular inhaled albuterol on exercise-induced bronchoconstriction. Am J Respir Crit Care Med 1996;153:65-9.

47. Chapman KR, Kesten S, Szalai JP. Regular vs as-needed inhaled salbutamol in asthma control. Lancet 1994;343:1379-82.

48. Pearlman DS, Chervinsky P, LaForce C, et al. A comparison of salmeterol with albuterol in the treatment of mild to moderate asthma. N Engl J Med 1992;327:1420-5.

49. Richter B, Buselic K, Heisters J, Richter A, Berger M. Continuous versus on demand inhaled $\beta$-agonist therapy on the basis of regular inhaled corticosteroids: a randomised controlled study. Eur Respir J 1995;8(Suppl 19):159s.

50. Peters MJ, Yates DH, Chung KF, Barnes PJ. Beneficial effect of $\beta_{2}$-agonist dose reduction in asthma. Aust NZ J Med 1994;24:460.

51. Sears MR. Dose reduction of beta-agonists in asthma. Lancet 1991;338:1331-2.

52. Inman WHW, Adelstein AM. Rise and fall of asthma mortality in England and Wales in relation to use of pressurised aerosols. Lancet 1969;ii:279-85.

53. Jackson RT, Beaglehole R, Rea HH, Sutherland DC. Mortality from asthma: a new epidemic in New Zealand. BMJ 1982;285:771-4.

54. Vital Statistics of the United States. Hyattsville: US Department of Health, Education and Welfare, National Center for Health Statistics, Public Health Service, Annual Reports 1977-87.

55. Mortality Statistics, England and Wales. London: Office of Population, Censuses and Surveys, Health Statistics, Annual Reports 1976-91.

56. Sears MR, Rea HH, Beaglehole R, et al. Asthma mortality in New Zealand: a two year national study. NZ Med J 1985;98:271-5.

57. Sears MR, Rea HH, De Boer G, et al. Accuracy of certification of deaths due to asthma. A national study. Am J Epidemiol 1986;124:1004-11.

58. Rea HH, Sears MR, Beaglehole R, et al. Lessons from the national asthma mortality study: circumstances surrounding death. NZ Med J 1987;100:10-3.

59. British Thoracic Association. Death from asthma in two regions of England. BMJ 1982;285:1251-5.

60. Johnson AJ, Nunn AJ, Somner AR, Stableforth DE, Stewart CJ. Circumstances of death from asthma. BMJ 1984;288:1870-2.

61. Barger LW, Vollmer WM, Felt RW, Buist AS. Further investigation into the recent increase in asthma death rates: a review of 41 asthma deaths in Oregon in 1982. Ann Allergy 1988;60:31-9.

62. Miller BD, Strunk RC. Circumstances surrounding the deaths of children due to asthma. A case-control study. Am J Dis Child 1989;143:1294-9.

63. Sur S, Crotty TB, Kephart GM, et al. Sudden onset fatal asthma. A distinct entity with few eosinophils and relatively more neutrophils in the airway submucosa? Am Rev Respir Dis 1993;148:713-9.

64. Ulrik CS, Frederiksen J. Mortality and markers of risk of asthma death among 1,075 outpatients with asthma. Chest 1995;108:10-5.

65. Spitzer WO, Suissa S, Ernst P, et al. The use of $\beta$-agonists and the risk of death and near death from asthma. N Engl J Med 1992;326:501-6.

66. Ernst P, Habbick B, Suissa S, et al. Is the association between inhaled beta-agonist use and life-threatening asthma because of confounding by severity? Am Rev Respir Dis 1993;148:75-9.

67. Suissa S, Blais L, Ernst P. Patterns of increasing $\beta$-agonist use and the risk of fatal or near-fatal asthma. Eur Respir J 1994;7:1602-9.

68. Committee on Safety of Medicines. Beta agonist use in asthma: report from the CSM Working Party [Report no 33]. London: CSM, 1992.

69. Taylor DR, Sears MR. Regular beta-adrenergic agonists. Evidence, not reassurance, is what is needed. Chest 1994;106:552-9.

70. McFadden ER, Gilbert IA. Asthma. N Engl J Med 1992;327:1928-37.

71. Ziment I. Beta2-agonists and their antagonists. Chest 1994;106:329-31.

72. Wanner $A$. Is the routine use of inhaled $\beta$-adrenergic agonists appropriate in asthma treatment? Yes. Am J Respir Crit Care Med 1995; $151: 597-9$.

73. Pearce N, Beasley R, Crane J, Burgess C, Jackson R. End of the New Zealand asthma mortality epidemic. Lancet 1995;345:41-4.

74. Ernst P, FitzGerald JM, Spier S. Canadian Asthma Consensus Conference: summary of recommendations. Can Respir J 19663:89-100. 


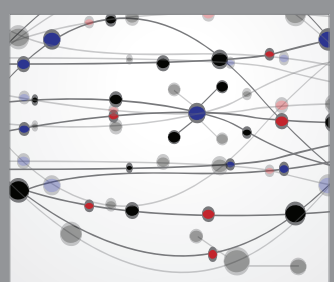

The Scientific World Journal
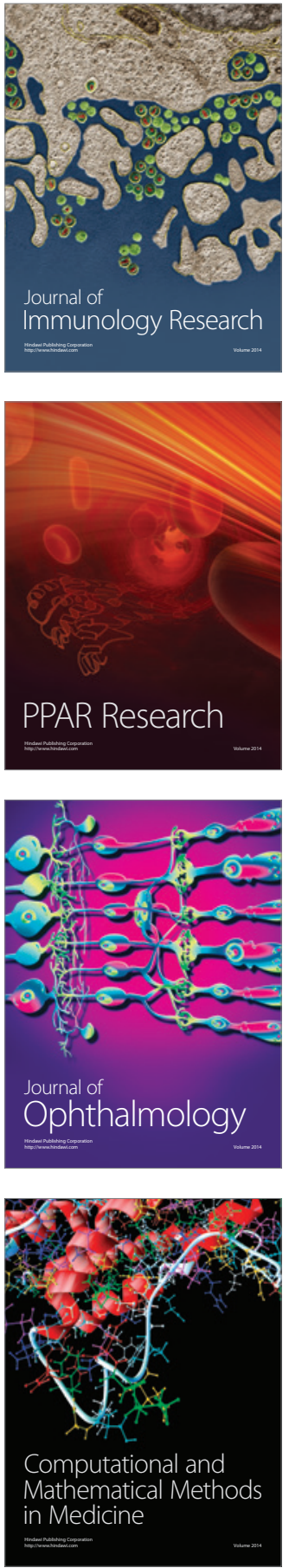

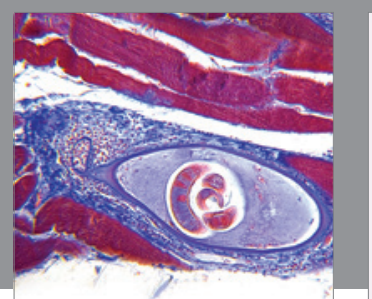

Gastroenterology Research and Practice

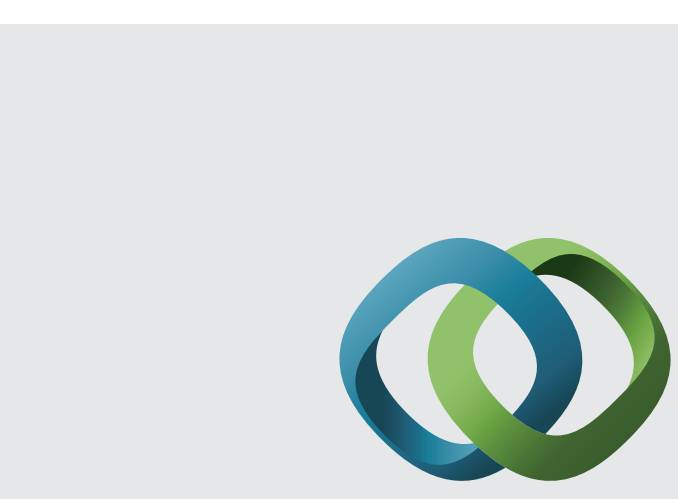

\section{Hindawi}

Submit your manuscripts at

http://www.hindawi.com
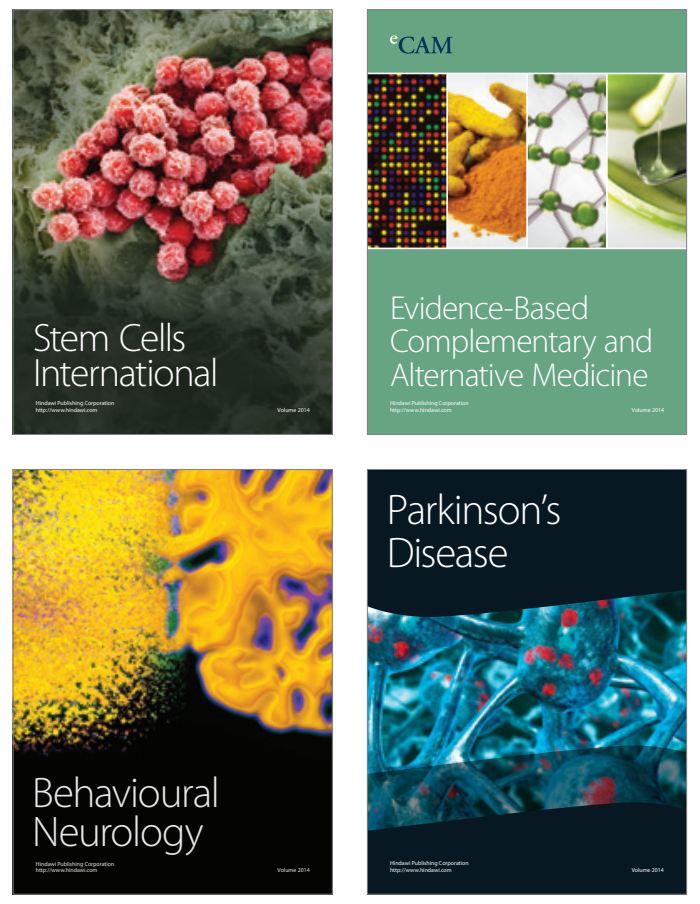
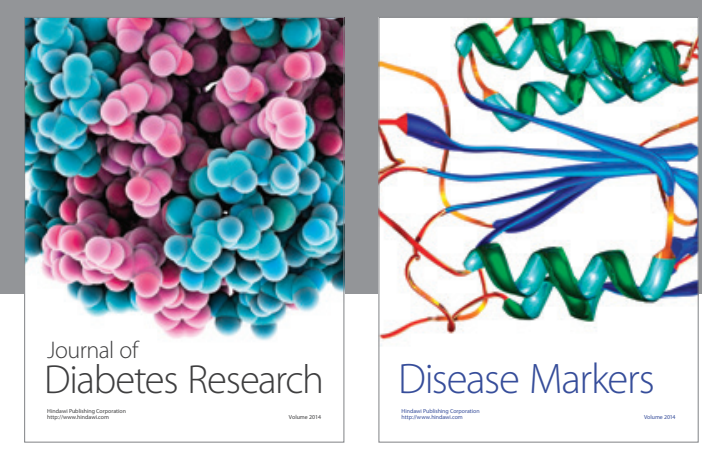

Disease Markers
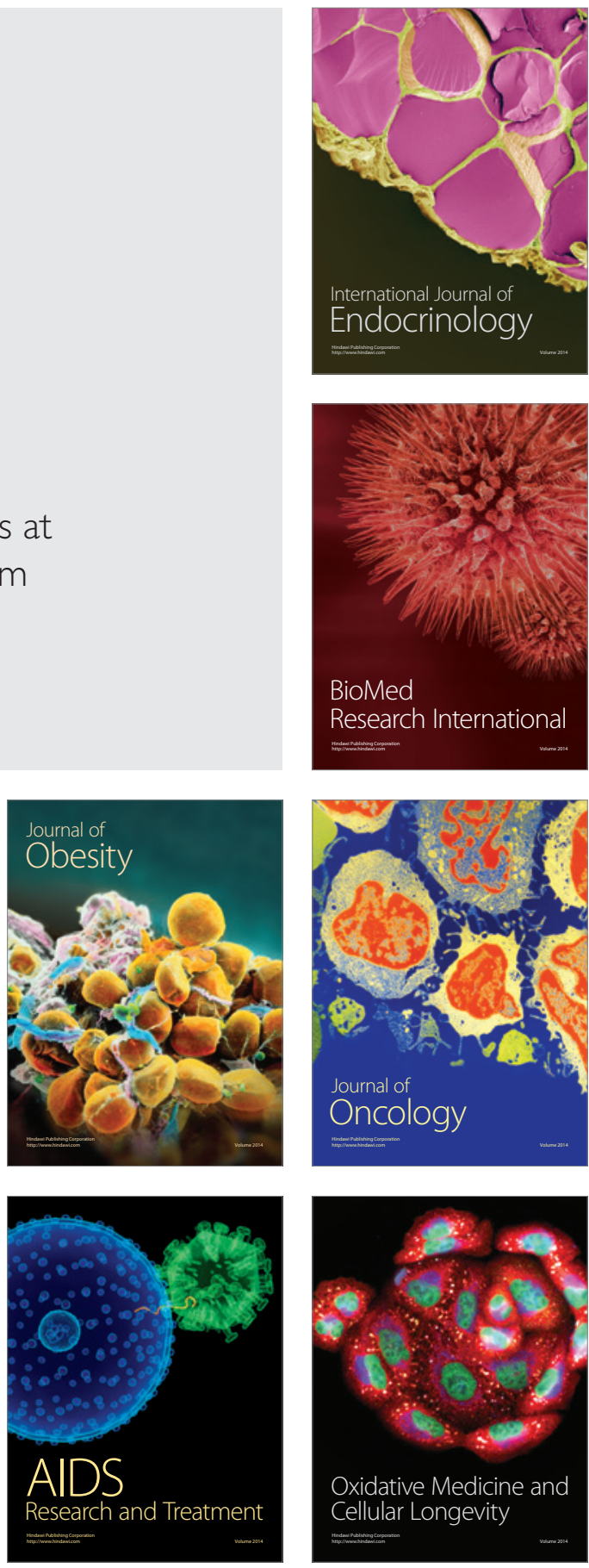